\title{
The contributions of civil society to food security in the context of COVID-19: a qualitative exploration in Uruguay
}

\author{
Gerónimo Brunet ${ }^{1, *} \odot$, Alejandra Girona ${ }^{1,2}$, Gabriela Fajardo2, Valentina Iragola', \\ Leandro Machín ${ }^{1,3}$, Isabel Bove ${ }^{4}$ and Gastón Ares ${ }^{1,5}$ \\ 'Núcleo Interdisciplinario Alimentación y Bienestar, Espacio Interdisciplinario, Universidad de la República, \\ Montevideo, Uruguay: ${ }^{2}$ Escuela de Nutrición, Universidad de la República, Montevideo, Uruguay: ${ }^{3}$ Centro de \\ Investigación Básica en Psicología, Facultad de Psicología, Universidad de la República, Montevideo, Uruguay: \\ ${ }^{4}$ UNICEF Uruguay, Montevideo, Uruguay: ${ }^{5}$ nstituto Polo Tecnológico de Pando, Facultad de Química, Universidad de \\ la República, Canelones, Uruguay
}

Submitted 24 March 2021: Final revision received 17 July 2021: Accepted 9 August 2021: First published online 16 August 2021

\begin{abstract}
Objective: The aim of this study was to explore and analyse the actions implemented by civil society to contribute to food security in the context of the COVID-19 outbreak in Uruguay, a high-income country in South America.

Design: An exploratory systematic approach was used to identify the contributions of civil society to food security through reports in news websites and Facebook posts. Data were analysed based on content analysis following a deductiveinductive approach.

Setting: Uruguay, Latin America.

Results: A total of 1220 civil society organisations were identified, which developed two main actions to increase access to food among the Uruguayan population: food baskets and 'community pots' (also known as 'common pots'). Most of the initiatives targeted citizens under socioeconomic vulnerability in the face of COVID-19, without specifying any specific requirement or population segment. Actions were mainly led by spontaneously organised community groups, and, to a lesser extent, by consolidated organisations. Interactions between organisations were identified. The foods provided by the organisations were mostly aligned with national dietary guidelines. Social media posts evidenced that the main challenge faced by organisations was related to the lack of funds or supplies. Conclusions: Results from this work suggest that the lack of funds or supplies poses challenges to the medium- and long-term contributions of civil society to food security and stresses the need for comprehensive governmental measures to guarantee food security amongst Uruguayan citizens.
\end{abstract}

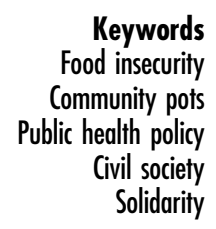

\section{Introduction}

The COVID-19 pandemic has led to the most important health, humanitarian, economic and social crisis the world has faced in recent times ${ }^{(1)}$. The measures implemented to contain the pandemic have had a major impact on economic activity worldwide, leading to an increase in unemployment and a decrease in household income ${ }^{(2)}$. One of the immediate consequences of the effects of COVID-19 on the economy is an increase in food insecurity ${ }^{(3,4)}$. According to the UN, the number of people living with acute hunger could have doubled in
2020, representing an additional 130 million people worldwide $^{(5)}$. This situation poses short- and long-term challenges for health and wellbeing and stress the need to implement strategies to secure access to food ${ }^{(6,7)}$.

The economic impact of COVID-19 pandemic in Latin America has been worse than in other regions of the world $^{(8,9)}$. Structural problems undermined the capacity of the region to mitigate the negative effects of the pandemic, including inequality, labour informality, low average wage, as well as weaknesses in health and social protection systems ${ }^{(10,11)}$. Latin American welfare states have been historically weak and their social protection 
systems show several inequalities ${ }^{(12)}$. Therefore, although governments implemented a series of measures to mitigate the negative economic and social effects of the pandemic ${ }^{(13)}$, income loss in the region during 2020 reached $15 \%$ for the occupied population and poverty rose from $30.5 \%$ in 2019 to $33.7 \%$ in $2020^{(11)}$. This situation motivated the emergence of different solidarity actions from civil society to help vulnerable segments of the population ${ }^{(14-16)}$.

Solidarity can be understood as the ability of members of a community to help and support each other ${ }^{(17)}$. Tragedies or crisis situations (e.g. wars or natural disasters) motivate modern societies to express solidarity and develop collective efforts to share responsibility and relieve the negative impacts caused by these phenomena ${ }^{(18)}$. Social networks of the community are fundamental for creating and sustaining solidarity through the circulation of information and resources ${ }^{(19)}$. 'Local interpersonal networks and interlocking institutions that serve the community and its members' play a transcendent role as transmission channels of solidarity sentiments ${ }^{(19)}$. Civil society institutions constitute empirical expressions of the ideals of solidarity among a community ${ }^{(20)}$. These institutions are considered different from other spheres such as the State, the market or the family ${ }^{(20)}$.

Civil society has played a major role in Latin American countries, becoming a key expression of the crisis of representation in current democracies ${ }^{(21)}$. During the XXI century, civil society organisations have contributed to the enforcement of human rights related to violence, food insecurity, poverty and gender in Latin American countries $^{(22)}$. However, their agendas have been mainly oriented to the diffusion of information and advocacy with national states ${ }^{(22)}$. Although their capacity to provide public goods is limited ${ }^{(21)}$, their efforts have been relevant during crisis situations ${ }^{(22)}$. In response to the COVID-19 crisis, civil society organisations of Latin American and Caribbean countries have developed a repertoire of actions that have contributed to others developed by national and local governments ${ }^{(11,14-16)}$. However, research on the response of civil society to the food crisis generated by the COVID-19 pandemic is still scarce. An in-depth understanding of such response can contribute to articulate experiences and knowledge in order to enhance countries' response to the short- and middle-term effects generated by different types of crises, such as natural tragedies or disasters.

\section{Aim of the study and context}

The aim of this study was to explore and analyse the actions implemented by civil society to contribute to food security in Uruguay in the context of the COVID-19 outbreak. In this study, civil society is defined as the part of the society distinct from government and commercial for-profit actors ${ }^{(20)}$.

Uruguay is a small high-income country located in South America, with approximately 3.5 million inhabitants.
It stands out in the region due to high levels of human development, low poverty rate and the lowest rate of income inequality of the region ${ }^{(23,24)}$. In addition, Uruguay is considered as one of the most advanced countries of the continent in terms of welfare and has a highly developed social protection system ${ }^{(25)}$. This makes the analysis of the response of the Uruguayan civil society in the context of the COVID-19 pandemic an interesting case study.

The first cases of the outbreak of coronavirus (COVID-19) in Uruguay were confirmed on March 13th, $2020^{(26)}$. Until November 2020, Uruguay managed to contain an exponential growth in COVID-19 cases without mandatory curfews or lockdowns ${ }^{(27)}$. The social distancing measures implemented by the Uruguayan government included closure of educational institutions, mass gathering cancellations, partial closure of workplaces and stay-at-home recommendations ${ }^{(28)}$.

The interruption of economic activities and the reduction of the demand of goods and services caused a severe economic crisis in the country ${ }^{(29)}$. This situation occurred in a context of reduced economic growth, increased unemployment and limited fiscal space after an unprecedented 15-year period of economic growth ${ }^{(30-32)}$. The Uruguayan government adopted a series of measures aimed at mitigating the economic and social negative effects derived from the COVID-19 pandemic in the country, which can be sorted into four major groups: (i) cash transfers and distribution of foods and hygiene products, (ii) measures to sustain employment levels and to alleviate losses in household income, (iii) measures to guarantee sufficient stocks of foods and hygiene products at reasonable prices and (iv) other measures to mitigate the effects of COVID-19 pandemic on economic activity (e.g. soft loans to the private sector, defer payments and discounts of taxes and utility services) $)^{(33)}$. However, these measures had a positive but limited effect on mitigating the poverty strike $^{(30)}$.

\section{Methods}

The study had an exploratory design aimed at systematically identifying the contributions of civil society to food security in the context of COVID-19 by studying news websites and social media posts.

\section{News websites}

News reports were retrieved through a hand search using Google with the search words 'solidaridity' and 'coronavirus' ('solidaridad' and 'coronavirus' in Spanish). A total of 96 news reports detailing contributions of the Uruguayan civil society to food security in the context of COVID-19 and published on Uruguayan news websites between March 13th (detection of the first cases of 
COVID-19 in Uruguay) and July 20th, 2020 were retrieved. A master list of organisations from the civil society was created.

\section{Social media}

Using the master list of organisations identified in the news websites, a search for Facebook accounts was performed using the search tool considering the name of the organisations as keywords. For each Facebook account, all the content posted from the detection of the first cases of COVID-19 in Uruguay (March 13th, 2020) until August 1 st, 2020 was extracted. Only posts related to contributions to food security were considered. Snowball sampling was used to identify additional organisations from the Facebook posts. A search for Facebook accounts of the identified organisations was performed. This procedure was repeated until no new organisations appeared.

\section{Data extraction and analysis}

News reports and Facebook posts were analysed using a deductive-inductive approach ${ }^{(34)}$. A deductive approach was used to select the topics of interest, which defined the data to be extracted from the reports and Facebook posts. The following information was extracted (if available) by one of the authors: (i) name of the civil society organisation, (ii) type of organisation, (iii) description of the actions implemented to increase access to food, (iv) target population, (v) planning and development of the actions and (vi) challenges faced by the organisations.

Within each of the topics (with the exception of topic i), the extracted information was analysed using an inductive approach. Codes were generated inductively for each topic as they emerged from the news reports and Facebook posts. The coding was performed by the author who extracted the data and revised by a second researcher. Three meetings between the researchers were held to revise the coding and to resolve disagreements by consensus. Food products identified in the reports and Facebook posts were analysed using the NOVA food classification system ${ }^{(35)}$.

Descriptive statistics were used to summarise the information related to two of the topics: type of organisation and actions implemented to contribute to food security. The rest of the information was qualitatively analysed.

\section{Results}

A total of 1220 civil society organisations that developed actions to increase access to food among the Uruguayan population were identified in the news reports and Facebook posts. Fifty-one percent of the organisations corresponded to community groups, i.e. informal or semi-formal groups of citizens organised at the level of families, neighbourhoods or educational institutions. Most of those organisations were created as a response to the economic crisis generated by COVID-19. The rest of the organisations corresponded to non-governmental organisations (11\%), sport and social clubs (10\%), afterschool clubs for children and adolescents (8\%), trade unions (7\%), educational institutions (5\%), faith-based organisations (5\%), cultural centres (3\%) and political organisations (1\%). These previously established organisations developed new lines of actions to contribute to food access in the context of COVID-19.

\section{Characteristics of the actions implemented to increase access to food}

The identified organisations implemented two main actions to increase access to food: distribution of food baskets and community pots or common pots ('ollas populares' in Spanish). Food baskets were distributed by $76 \%$ of the organisations. Examples of the baskets provided by the organisations are shown in Fig. 1. According to the Facebook posts, the baskets mainly consisted of minimally processed foods, culinary ingredients and processed foods, such as rice, flour, maizemeal, lentils, oil, dried pasta, powdered milk and canned vegetables. Some of the posts evidenced that a minority of the organisations delivered baskets that also included fresh fruits and vegetables. In addition, the food baskets of one of the organisations included ultra-processed products (cookies, crackers and chocolate), as exemplified in Fig. 1 (right bottom corner). This organisation was created by a group of private companies, four of which produced ultraprocessed products.

Sixty-two percent of the identified organisations were responsible for community pots or common pots, which can be regarded as self-managed popular dining rooms. Community pots consisted of improvised food service facilities, located at sport clubs, cultural centres, houses or even on the street, that provided free hot meals and snacks to the most vulnerable population. They were positioned as the main symbol of the civil society response to COVID-19 in the media news reports. As exemplified in Fig. 2, most community pots prepared meals on stainlesssteel pots over a stove or a fire of woods. Stews and pasta were the most common meals provided by community pots. In addition, some organisations also provided breakfast and afternoon snack, which mainly consisted of milk and bread. In most cases, people attending community pots took plastic containers to take the meal, whereas other organisations provided disposable containers to beneficiaries.

Fifteen percent of the identified organisations were not in direct contact with the beneficiaries. Instead, they acted as nexus between organisations. They were mainly in charge of receiving donations from citizens, companies or other civil society organisations, which were then distributed to other organisations in direct contact with beneficiaries. It is worth highlighting that some of these 
COVID-19: civil society and food security
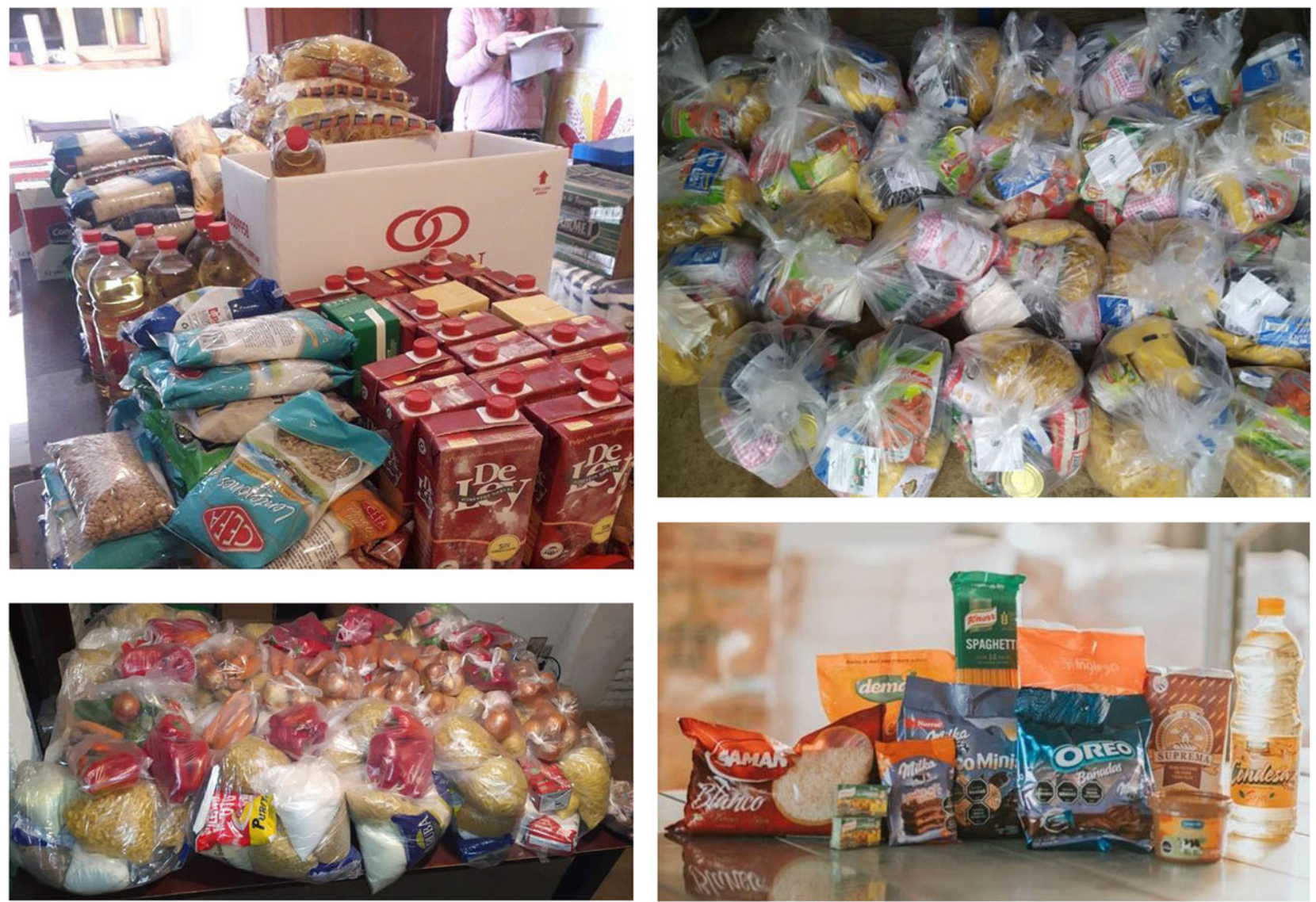

Fig. 1 (colour online) Images of food baskets distributed by Uruguayan civil society organisations in the context of COVID-19, retrieved from the Facebook accounts of the organisations

organisations received donations of ultra-processed products from food companies (e.g. soda, crackers, cookies, chocolates), as exemplified in Fig. 3.

\section{Target population}

The information posted on Facebook evidenced that most of the organisations did not target their actions to any specific segment of the population. Instead, actions were targeted at any citizen who needed assistance in the context of COVID-19. Organisations used social media to disseminate information about their actions to potential beneficiaries, as exemplified in the following quotes taken from Facebook posts:

Important. Families who have received baskets and that still need support: Please contact us at (cell phone number) to ask for the benefit in June'

'Today one of our neighbors will organize the afternoon snack. Pastries, cookies, etc. You are all invited'

'Tomorrow, the community pot changes its schedule due to the demonstrations. On Thursday 4th, we'll receive you at 11:30. Bring your container. We'll be waiting for you at (address)'.
Only $18 \%$ of the organisations targeted their actions towards specific segments of the population, such as families with children and adolescents, elderly, immigrants or homeless people. Most of those organisations were established before COVID-19 and incorporated specific lines of actions to address the challenges faced by their target population in the context of the outbreak.

\section{Planning and development of the actions}

Facebook posts evidenced interactions between organisations and the existence of networks, which provided synergy to the actions. Several organisations acted as nexus between organisations, whereas other organisations jointly distributed food baskets or organised community pots. Networks of community pots were identified in several neighbourhoods of the capital city, Montevideo, which enabled the exchange of foods and other relevant inputs.

Funding of the organisations for the food baskets and community pots was based on donations and, to a lesser extent, their own funds. Donations were mainly obtained from citizens, although references to companies, international organisations, other civil society organisations, the national government and local governments were also identified. Some organisations requested donations of 

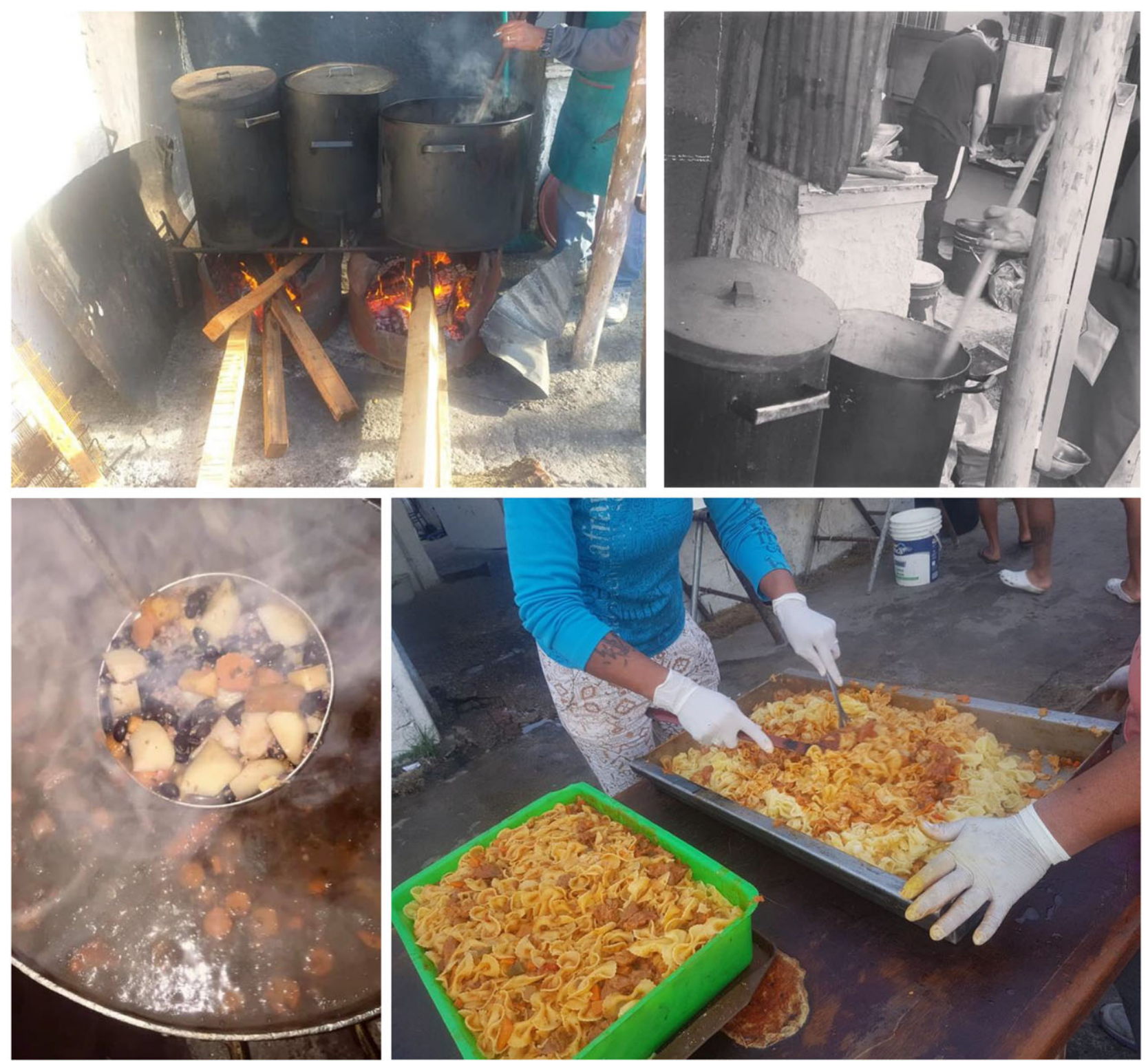

Fig. 2 (colour online) Images of community pots organised by Uruguayan civil society organisations in the context of COVID-19, retrieved from the Facebook accounts of the organisations

specific products (e.g. 'We receive donations of onion, pepper, tomato sauce, lentils, beans, flour and eggs' or 'Collaborate by donating oil, sugar, salt, fat, baking powder or cleaning products'), whereas others requested any kind of donations (e.g. 'Second round of collection of foods and cleaning products. We will use everything we collect to prepare baskets for the families with children and adolescents that participate in our activities or 'Sponge cake? Cookies? Scones? Bread? What is your specialty? Be part of this initiative by bringing something home-made for this Wednesday'). Reliance on donations of foods introduced variations to the content of the food baskets provided by the organisations and the dishes prepared in the community pots.
The organisations developed a large range of strategies to raise funds or collect donations of foods and other supplies, including fundraising campaigns, sales of foods or other goods and raffles. Examples of the posts describing fundraising strategies are provided below:

'We are still receiving donations. Contact us at (cellphone number) and we will collect your donation. We put together food baskets and distribute them to different organizations. Thank you'

'Thank you! To all those companies and people who collaborate with us in these special times of vulnerability. We wouldn't be able to do it without you. You can contribute with $\$ 100$ per month by calling at (number)' 


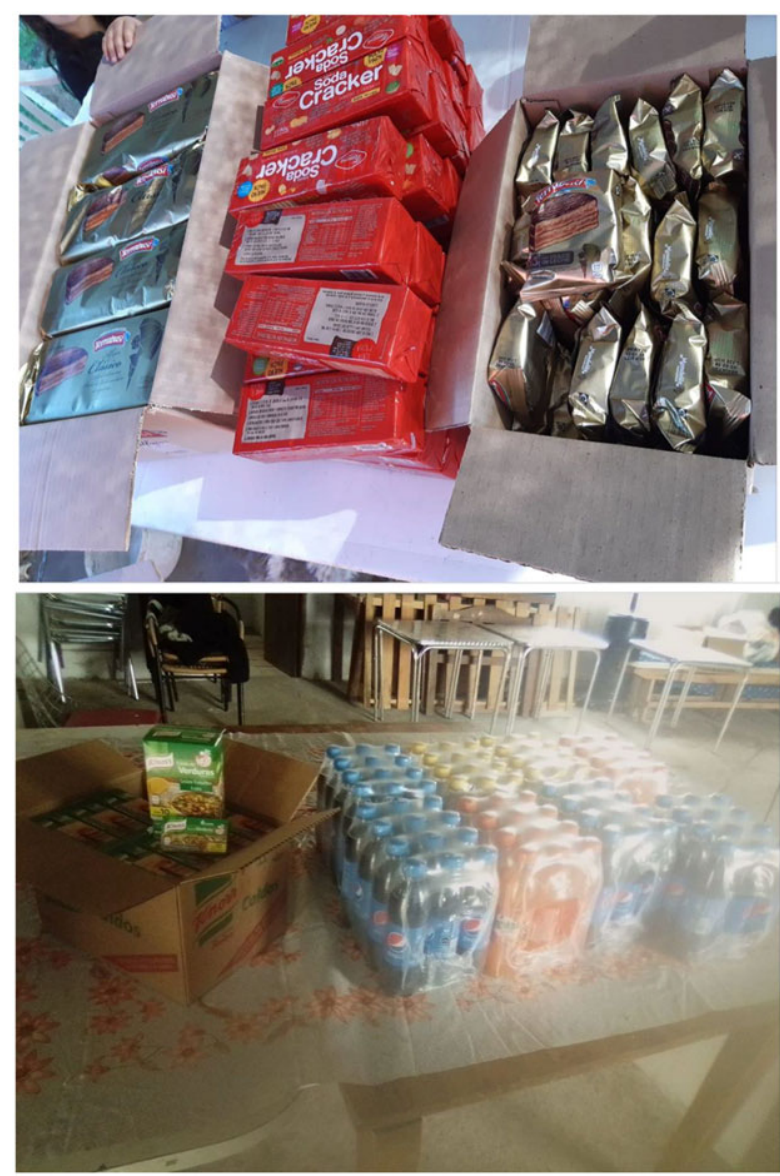

Fig. 3 (colour online) Images of donations of ultra-processed products received by Uruguayan civil society organisations in the context of COVID-19 from a food bank

'We need your belp. During the sanitary emergency there are many families that cannot access basic food. We are putting together food baskets that are distributed to more than 100 families every week. How can you collaborate? (Banking information)'

'Solidary day. Sale of jams. Apple jam - Pumpkin jam. This is one of the ways we have to keep our solidary actions going. And it's tasty!'

'Solidary Friday. Sales of pastry to keep our community pot working. We'll be receiving orders until Wednesday 13th. We will be delivering the orders on Friday 15th. All the funds will be used to pay the costs of our community post. You can order yours to one of the neighbors that are belping us'

Large differences between the organisations were identified in terms of the planning of the actions. Some organisations, particularly non-governmental organisations, faith-based organisations, trade unions and educational institutions, planned their actions in advance to address the needs of the population.

\section{Challenges faced by the organisations}

The main challenge faced by the organisations was related to the lack of funds or supplies. From May 2020, there was an increase in the number of posts referring to a reduction in the number of donations and lack of foods for the food baskets or the community pots, as exemplified in the following quote: 'Next week we'll be able to cover only 2 snacks. After 2 months of continued work, we're really sorry. We are providing 52 to 55 liters of milk per day for 234 people!!! We need your help to keep helping these people!! With 1 liter/1 kilo you are helping. Thanks for sharing!!'.

Due to the lack of donations, some organisations were forced to discontinue their actions (e.g. 'Due to the lack of donations, we are not receiving anything, there won't be preparing more baskets until further notice. There's nothing else we can do') or restricted their target population (e.g. 'Today is our last community pot. From tomorrow, only for children...').

In addition, from the beginning of May, several organisations announced the interruption of their activities, mainly due to difficulties to obtain funding or the return of organisations and volunteers to their normal activities. In the following, examples of posts are provided:

'Good morning! As everything else in life, it finishes. This Thursday our community pot will come to an end. As it is well-known, people in charge (of the pot) started with their normal activities. In addition, donations are not coming, and it is very difficult for us to continue. We would like to thank all the neighbors that came to us with a package of pasta, to the companies, etc. Thank you very much! We are very gratefulfor having been able to help so many people'

(Name of the sport club) communicates that today (27/5) will be our last community pot. We thank all who have collaborated to develop this initiative, from those who donated supplies to those who prepared the meals. Thanks everyone'

'Thanks for your solidarity. We inform that the popular pot won't continue. We hope we have been able to belp those in need during these two months. We have given our biggest effort and dedication, always for the sake of our neighborbood. Thanks to those who made it possible

\section{Discussion and conclusions}

Results of this study showed that Uruguayan civil society developed a large number of actions to contribute to food security in the context of the COVID-19 pandemic, in agreement with previous studies conducted in different countries across the world ${ }^{(14-16,36-40)}$. The large number of organisations that developed activities to contribute to food security indicates that the actions implemented by 
the Uruguayan government were not enough to contain the negative effects of the COVID-19 pandemic. This suggests failures in the social protection system and welfare regime of Uruguay, as previously reported for other Latin American and Caribbean countries ${ }^{(11)}$. The pandemic evidenced the need to reconfigure the food, health and social protection systems of Latin American countries to guarantee the achievement of food security ${ }^{(41)}$.

The large number of organisations that developed activities to contribute to food security can be seen as a sign of expression of solidarity within the Uruguayan population ${ }^{(19)}$. Most of the initiatives targeted any citizen under socioeconomic vulnerability in the face of COVID-19, without specifying any specific requirement or population segment. This suggests the broad extension of the response of the Uruguayan civil society and represents a key difference with results reported by a Latin American study focussed on activities developed in informal settlements ${ }^{(14)}$.

The contributions of Uruguayan civil society to food security were mainly led by community groups, and, to a lesser extent, by consolidated organisations. Other studies conducted in different regions of the world have also reported the spontaneous creation of initiatives to respond to the urgent needs of vulnerable segments of the population in the context of the pandemic ${ }^{(14,37,40)}$. However, the creation of these initiatives highlights the existence of an 'associative fabric', i.e. a network of groups and civil society organisations, that preceded the COVID-19 pandemic and enabled a rapid response during the crisis $^{(14)}$. In this sense, the present work evidenced the existence of interactions between community groups and consolidated organisations.

The interactions between organisations can be regarded as examples of circulation of information and resources, fundamental activities to generate and maintain social solidarity $^{(19)}$. Results from the present work evidenced articulation and creation of networks among different civil society organisations rather than between the organisations and State institutions. Furthermore, citizens were the main source of funding for the actions implemented by civil society, while contributions from for-profit organisations and governmental institutions (from the national and local governments) were secondary. This is aligned with conceptual frameworks which highlight that civil society is independent from other spheres, such as the State or the market ${ }^{(19,20,42)}$.

Social media posts evidenced that most civil society organisations did not establish close relationships with governmental institutions. However, instances where governmental institutions provided foods or other resources to the organisations were identified. The lack of coordination and alliance between civil society and State organisations can have a negative effect in their ability to cope with the crisis $^{(43,44)}$. In this sense, Duque Franco et al. ${ }^{(14)}$ outlined that the discordances between civil society initiatives and State measures have had a negative impact on their ability to improve the lives of vulnerable citizens in Latin American countries, for example in terms of security and transportation.

In this sense, a closer relationship between civil society organisations and governmental institutions could have synergistic effects. The incorporation of the knowledge and experience of civil society organisations can contribute to increase the efficacy of governmental responses in the context of the COVID-19 outbreak or any other food crisis $^{(14,45)}$. Although States should be the main responsible for guaranteeing food security in the country ${ }^{(46)}$, civil society organisations should be regarded as strategic partners in all stages of the design, implementation and assessment of governmental actions. Moreover, it seems necessary to adopt alternative approaches based on the reinterpretation of civil society as part of the democratic state and the public space $^{(16)}$. The development of public actions through societal-state associations of co-construction and collaborative learning can generate important contributions to the achievement of solutions to new problems derived from the crisis ${ }^{(16,47)}$.

Social media seemed to play a fundamental role for the coordination, execution and diffusion of the actions developed by Uruguayan civil society to contribute to food security in the context of COVID-19. The fundamental role played by information and communication technologies in the context of COVID-19 has been stressed by other authors ${ }^{(14,37,39)}$. Common examples of the activities conducted through information and communication technologies included communication, fundraising, receipt of donations, ensuring accountability for the organisation's actions, recognition of the beneficiary population and application of collaborative mapping.

Uruguayan civil society developed two main strategies to increase access to food: food baskets and community pots. The same strategies have been identified in other countries of the region ${ }^{(14)}$. These initiatives have a long tradition in Latin American countries in the context of economic crises ${ }^{(14,48)}$. In Latin America, community pots have not only had the instrumental aim of providing food, but have also been associated with political struggles and the promotion of alternative cultural values ${ }^{(48)}$. In Uruguay, community pots emerged in 1980s, during the final part of the civil-military dictatorship occurred between 1973 and $1985^{(49,50)}$, and were also relevant during the last economic crisis in $2002^{(51)}$. According to Midaglia ${ }^{(50)}$, the emergence of community pots in Uruguay was linked to innovative forms of collective action that questioned aspects of the traditional societal model promoted by the State, political parties, trade unions and business unions. This suggests that the collective actions developed in the context of the crisis generated by the COVID-19 outbreak are not new. Instead, they are related to a rich history of social mobilisation in the country. 
In spite of the heterogeneous characteristics of the organisations, community pots were mainly organised at improvised food service facilities, sport clubs, cultural centres or even on the street. This can be attributed to the existence of logistic difficulties for the implementation of food security initiatives in Latin American countries ${ }^{(14)}$. In the case of Uruguay, these problems cannot be considered separately from the context where the initiatives were developed, as they were instrumented shortly after the implementation of the first social distancing measures in the country. In this sense, it is likely that the rapid organisation of the civil society response could have hindered optimal planning, coordination and execution. In addition, the relatively low levels of experience of many newly created associations could have contributed to this scenario.

Regarding the types of foods provided by civil society organisations, they consisted of natural or minimally processed foods, culinary preparations and, to a lesser extent, processed products. This is aligned with the recommendations provided by national dietary guidelines ${ }^{(52)}$. However, it is worth highlighting that social media posts suggested that the characteristics of the foods included in the baskets and the meals provided by community pots were strongly dependent on the type of donations received.

Food baskets containing ultra-processed products with excessive content of sugar, fat and sodium were identified, mainly when the organisations received donations from the food industry. The ultra-processed food industry has made donations to communities as part of their strategic responses during COVID-19 pandemic ${ }^{53,54)}$. These donations are often regarded as a contribution to food security. However, they are also part of the marketing strategies of the food industry as they enable the distribution and promotion of products close to expiration date in the context of reduced sales to the most vulnerable populations ${ }^{(53,54)}$. Therefore, it seems necessary to develop strategies to discourage inclusion of ultra-processed products with excessive content of nutrients associated with non-communicable diseases as part of the foods provided by civil society in the context of COVID-19. Considering the increasing relevance of food banks ${ }^{(15,55,56)}$, it seems necessary to progress in the design of guidelines and policies aimed at organising, regulating, orientating and facilitating food donation activities $^{(56,57)}$. In this sense, it is worth highlighting that the Uruguayan government implemented a protocol that banned donations of ultra-processed products to the State in the context of the COVID-19 pandemic, in an attempt to protect the most vulnerable population from the negative health consequences of sustained consumption of such products ${ }^{(58)}$.

The main challenge faced by the organisations was related to the lack of funds or supplies, which generated interruptions in their actions or restrictions on their target population. This result is aligned with the work of Tandon \& Aravind ${ }^{(36)}$, who reported a reduction in the resources of Indian civil society organisations from the sixth month of the response due to reduced donations.
Considering that the absence of proper social, economic and political conditions may threaten the viability of civil society organisations ${ }^{(59)}$, results from the present work highlight challenges for the medium- and long-term contribution of the Uruguayan civil society to food security. Therefore, governmental measures are fundamental to assure food security ${ }^{(7)}$. Additionally, although civil society organisations of Latin American countries present limited capacity for providing public goods to communities ${ }^{(21,22)}$, the recognition of their voice and initiatives is vital to advance towards new models of development for the societies of the region $^{(11)}$.

\section{Acknowledgements}

Acknowledgements: None. Financial support: Funding was obtained from UNICEF Uruguay and Espacio Interdisciplinario (Universidad de la República, Uruguay). The funding sources had no involvement in the study design, collection, analysis and interpretation of data, writing of the article, nor in the decision to submit it for publication. A researcher from UNICEF was involved in the conceptualisation of the study, interpretation of the results and writing of the manuscript. Conflict of interest: None. Authorship: All authors contributed to the development of the research. G.A. and G.B. analysed the data. G.A. and G.B. prepared a first version of the paper, to which all other authors then contributed substantially. Ethics of human subject participation: Not applicable. The information was retrieved from public websites and Facebook accounts of different institutions and organisations.

\section{References}

1. Hevia C \& Neumeyer A (2020) A Conceptual Framework for Analyzing the Economic Impact of COVID-19 and Its Policy Implications. New York: United Nations Development Programme.

2. International Labour Organization (2020) Policy Brief. A Policy Framework for Tackling the Economic and Social Impact of the COVID-19 Crisis. International Labour Organization. https://www.ilo.org/wcmsp5/groups/public/ @dgreports/@dcomm/documents/briefingnote/wcms_745337. pdf (accessed March 2021).

3. Paslakis G, Dimitropoulos G \& Katzman DK (2020) A call to action to address COVID-19-induced global food insecurity to prevent hunger, malnutrition, and eating pathology. Nutr Rev 79, 114-116.

4. Torero M (2020) Without food, there can be no exit from the pandemic. Nature 580, 588-589.

5. United Nations (2020) Policy Brief: The Impact of COVID-19 on Food Security and Nutrition. New York: United Nations. https://www.un.org/sites/un2.un.org/files/sg_policy_brief_ on_covid_impact_on_food_security.pdf (accessed March 2021).

6. Butler MJ \& Barrientos RM (2020) The impact of nutrition on COVID-19 susceptibility and long-term consequences. Brain Behav Immun 87, 53-54. 
7. O'Hara S \& Toussaint EC (2021) Food access in crisis: food security and COVID-19. Ecol Econ 180, 106859.

8. Burki T (2020) COVID-19 in Latin America. Lancet Infect Dis 20, 547-548.

9. Callejas D, Echevarría JM, Carrero Y et al. (2020) The SARS$\mathrm{CoV}-2$ pandemic in Latin America: the need for multidisciplinary approaches. Curr Trop Med Rep 7, 120-125.

10. International Labour Organization (2020) Impact on the Labour Market and Income in Latin America and the Caribbean. Lima: International Labour Organization. https:// www.ilo.org/wcmsp5/groups/public/—americas/—ro-lima/ documents/publication/wcms_756697.pdf (accessed July 2021).

11. Economic Commission for Latin America and the Caribbean (2021) Social Panorama of Latin America. Santiago: Economic Commission for Latin America and the Caribbean. https:/www.cepal.org/en/publications/46688-social-panoramalatin-america-2020 (accessed July 2021).

12. Economic Commission for Latin America and the Caribbean (2010) Time for Equality: Closing Gaps, Opening Trails. Thirty-third Session of ECLAC. Santiago: Economic Commission for Latin America and the Caribbean. https:// www.cepal.org/en/publications/3066-time-equality-closinggaps-opening-trails-thirty-third-session-eclac (accessed July 2021).

13. International Monetary Fund (2021) Policy Responses to COVID-19. International Monetary Fund. https://www.imf. org/en/Topics/imf-and-covid19/Policy-Responses-to-COVID-19 (accessed March 2021).

14. Duque Franco I, Ortiz C, Samper J et al. (2020) Mapping repertoires of collective action facing the COVID-19 pandemic in informal settlements in Latin American cities. Environ Urban 32, 523-546.

15. Basilico N \& Figueroa D (2020) Los bancos de alimentos y su rol durante la pandemia del COVID-19 [Food banks and their role during the COVID-19 pandemic]. Estud Soc 30, 2-28.

16. Andion C (2020) Atuação da sociedade civil no enfrentamento dos efeitos da COVID-19 no Brasil [The role of civil society in confronting the effects of COVID-19 in Brazil]. Rev de Adm Publica 54, 936-951.

17. Schiermer B (2014) Durkheim's concept of mechanical solidarity - Where did it go? Durkheimian Stud 20, 64-88.

18. Alfirdaus LK, Hiariej E \& Adeney-Risakotta F (2015) Theories of social solidarity in the situations of (natural) disasters. Politik 6, 44-70.

19. Hawdon J \& Ryan J (2011) Social relations that generate and sustain solidarity after a mass tragedy. Soc Forces $\mathbf{8 9}$, 1363-1384.

20. Alexander JC (2006) The Civil Sphere. New York: Oxford University Press.

21. Sorj B (2007) ¿Pueden las ONG reemplazar al Estado? Sociedad Civil y Estado en América Latina [Can NGOs replace the State? Civil Society and State in Latin America]. NUSO 210, 126.

22. Marín-Arangureny EM \& González Jaramillo D (2020) Recorrido por las acciones de las organizaciones civiles de derechos humanos en América Latina [Tour of the actions of civil human rights organizations in Latin America]. Razón Crítica 8, 21-53.

23. World Bank (2021) Datos Uruguay [Uruguay Data]. World Bank. https://datos.bancomundial.org/pais/uruguay?year= 2018 (accessed July 2021)

24. United Nations Development Programme (2020) The 2020 Human Development Report. The Next Frontier Human Development and the Anthropocene. New York: United Nations Development Programme. http://hdr.undp.org/ sites/default/files/hdr2020.pdf (accessed July 2021).

25. Filgueira F \& Hernández D (2012) Sistemas de protección social en América Latina y el Caribe: Uruguay [Social Protection Systems in Latin American and the Carribean:
Uruguay]. Montevideo: Economic Commission for Latin America and the Caribbean. https://repositorio.cepal.org/ bitstream/handle/11362/4036/1/S1201032_es.pdf (accessed July 2021).

26. Presidencia de la República (2020) Información actualizada sobre coronavirus COVID-19 en Uruguay [Updated Information about Coronavirus COVID-19 in Uruguay]. Montevideo: Presidencia de la República Oriental del Uruguay.

27. Taylor F (2020) Uruguay is winning against covid-19. This is how. BMJ 370, m3575.

28. Roser M, Ritchie H, Ortiz-Ospina E et al. (2020) Coronavirus Pandemic (COVID-19). Our World in Data. https:// ourworldindata.org/coronavirus (accessed March 2021).

29. Capurro A, Deagosto G, Ferro F et al. (2020) Impacto social $y$ económico del COVID-19 y opciones de politicas en Uruguay [Social and Economic Impact of COVID-19 and Policy Options for Uruguay]. Montevideo: Programa de las Naciones Unidas para el Desarrollo. https://www.uy.undp. org/content/uruguay/es/home/library/poverty/Impacto_social_ economico_COVID19_Uruguay.html/ (accessed March 2021).

30. Brum M \& De Rosa M (2020) Too Little But Not Too Late. Nowcasting Poverty and Cash Transfers' Incidence in Uruguay during COVID-19's Crisis (Working Document 09/2020.). Montevideo: Universidad de la República. http://www.iecon.ccee.edu.uy/dt-09-20-too-little-but-nottoo-late-nowcasting-poverty-and-cash-transfers-incidence-inuruguay-during-covid-19-s-crisis/publicacion/729/es/ (accessed March 2021).

31. Barquín J \& Zufriategui MP (2018) Uruguay y la regla fiscal. Un cambio de rumbo necesario [Uruguay and the Fiscal Rule. A Necessary Change of Course]. Montevideo: Academia Nacional de Economía.

32. International Monetary Fund (2020) 2019 Article IV Consultation - Press Release; Staff Report; and Statement by the Executive Director for Uruguay. International Monetary Fund. https://www.imf.org/en/Publications/CR/Issues/2020/ 02/20/Uruguay-2019-Article-IV-Consultation-Press-ReleaseStaff-Report-and-Statement-by-the-49065 (accessed March 2021).

33. Brunet G, Girona A, Fajardo G et al. (2020) Colección Salud y Bienestar. La respuesta de Uruguay frente a la crisis generada por el coronavirus (COVID-19). Acciones del Estado uruguayo para favorecer el acceso a alimentos y productos de bigiene [Collection Health and Wellbeing. The Response of Uruguay to the Crisis Generated by Coronavirus (COVID-19). Actions of the Uruguayan State to Facilitate Access to Foods and Hygiene Products]. Montevideo: UNICEF Uruguay.

34. Krippendorff K (2004) Content Analysis: An Introduction to Its Methodology. Thousand Oaks, CA: Sage Publications.

35. Monteiro C, Cannon G \& Lawrence M (2019) Ultra-processed Foods, Diet Quality, and Health Using the NOVA Classification System. Rome: FAO.

36. Tandon R \& Aravind R (2020) Source of Life or Kiss of Death: revisiting state-civil society dynamics in India during COVID19 pandemic. De Gruyter 12, 147-163.

37. Gutierrez F (2020) Solidaridad y participación en una sociedad desigual: la Covid-19 en Filipinas [Solidarity and participation in an unequal society: Covid-19 in Philippines]. In Alerta global. Políticas, movimientos sociales y futuros en disputa en tiempos de pandemia [Global Alert. Policies, Social Movements and Futures in Dispute in Times of Pandemic], pp. 133-140 [B Bringel \& G Pleyers, editors]. Lima: CLACSO.

38. Nubari Francis N \& Pegg S (2020) Socially distanced schoolbased nutrition program under COVID 19 in the rural Niger Delta. Extr Ind Soc 7, 576-579.

39. Sharma SV, Haidar A, Noyola J et al. (2020) Using a rapid assessment methodology to identify and address immediate 
needs among low-income households with children during COVID-19. PLoS One 15, e0240009.

40. Banerjee S (2020) Espacios comunitarios en la India: ¿construyendo solidaridad en tiempos de pandemia? [Community spaces in India: building solidarity in times of pandemic?]. In Alerta global. Políticas, movimientos sociales $y$ futuros en disputa en tiempos de pandemia [Global Alert. Policies, Social Movements and Futures in Dispute in Times of Pandemic], pp. 141-146 [B Bringel \& G Pleyers, editors]. Lima: CLACSO.

41. Pérez-Escamilla R, Cunningham K \& Moran VH (2020) COVID-19 and maternal and child food and nutrition insecurity: a complex syndemic. Matern Child Nutr 16, e13036.

42. Greer SL, Wismar M, Pastorino G et al. (2011) Civil Society and Health. Copenhaguen: WHO Regional Office for Europe.

43. Sobel RS \& Leeson PT (2006) Government's response to Hurricane Katrina: a public choice analysis. Public Choice 127, 55-73.

44. Ertan G (2020) Civil society and disaster management: case of Marmara earthquake. ESOSDER 19, 2044-2056.

45. Ortiz C \& Di Virgilio MM (2020) Laboratorios de Vivienda (LAVs). Asentamientos precarios y vivienda social: impactos del covid-19 y respuestas [Housing Laboratories (LAVs). Slums and social housing: impacts of COVID-19 and responses]. https://eurosocial.eu/wp-content/uploads/2020/ 06/LAV-Impactos-de-la-crisis-del-COVID-19-en-aaii-130420.pdf (accessed April 2021).

46. Food and Agriculture Organization (2013) Ley Marco. Derecho a la alimentación, seguridad y soberanía alimentaria [Framework Law. Right to Food, Security and Food Sovereignty]. Panamá: Food and Agriculture Organization of the United Nations. http://www.fao.org/fileadmin/ templates/righttofood/documents/project_m/doc/Ley_Marco_ DA_Parlartino.pdf (accessed March 2021).

47. Sabel C \& Zeitlin J (2012) Experimentalist governance. In The Oxford Handbook of Governance, pp. 1-17 [D Levi-Faur, editor]. Oxford: Oxford University Press.

48. Pereyra Cousiño B (2016) Los significados del comedor popular: entre los intereses estratégicos y prácticos [The Meanings of the Popular Dining Room: Among Strategic and Practical Interests]. La Plata: Universidad Nacional de La Plata.

49. Delbene L (2014) Ediciones de Uno: poesía en la resistencia y reactivaciones de la vanguardia [Editions of One: Poetry in the resistance and reactivations of the avant-garde]. Cuad Hist 13, 77-98.

50. Midaglia C (1992) Las formas de acción colectiva en Uruguay [Collective Forms of Action in Uruguay]. Montevideo: Centro de Informaciones y Estudios del Uruguay.

51. Graña F \& de Sierra G (2004) Uruguay: pobreza y exclusión duraderas. De la integración social a la fragmentación estructural [Uruguay: enduring poverty and exclusion. From social integration to structural fragmentation]. In El Uruguay desde la sociologia II [Uruguay from the Sociology II], pp. 249-262 [E Mazzei, compilator]. Montevideo: Graphis.

52. Ministerio de Salud Pública (2016) Guía alimentaria para la población uruguaya [Dietary Guidelines for the Uruguayan Population]. Montevideo: Ministerio de Salud Pública.

53. Collin J, Ralston R, Hill SE et al. (2020) Signalling Virtue, Promoting Harm: Unbealthy Commodity Industries and COVID-19. Geneva: NCD Alliance, SPECTRUM.

54. Antúnez L, Alcaire F, Brunet G et al. (2021) COVIDwashing of ultra-processed products: The content of digital marketing on Facebook during the COVID-19 pandemic in Uruguay. Public Health Nutr. doi: 10.1017/S136898002 1000306.

55. Mejía G, Mejía C, Rangel V et al. (2013) Food Donation: An Initiative to Mitigate Hunger in the World. Rome: Food and Agriculture Organization of the United Nations.

56. Schneider F (2013) The evolution of food donation with respect to waste prevention. Waste Manag 33, 755-763.

57. European Commission (2017) Commission Notice of 16.10.2017. EU Guidelines on Food Donation. Brussels: European Commission.

58. Ministerio de Desarrollo Social (2020) Donaciones COVID19 [COVID-19 Donations]. Montevideo: Presidencia de la República Oriental del Uruguay.

59. Salamon LM \& Anheier HK (1997) The civil society sector. Society 34, 60-65. 